\title{
Investigation of The Effects of Serum Iron and Copper Levels in Ischemic Stroke Disease Development
}

\author{
İskemik Inme Hastalığı Gelişiminde Serum Demir ve Bakır Düzeylerinin \\ Etkilerinin Araştırılması
}

\author{
Arzu Ay ${ }^{1}$, Nevra Alkanli ${ }^{2}$, Sezgin Kehaya ${ }^{3}$ \\ ${ }^{1}$ Department of Biophysics, Faculty of Medicine, Trakya University, Edirne, Turkey \\ ${ }^{2}$ Department of Biophysics, Faculty of Medicine, Halic University, Istanbul, Turkey \\ ${ }_{3}^{3}$ Department of Neurology, Faculty of Medicine, Trakya University, Edirne, Turkey
}

\begin{abstract}
Objective: Ischemic stroke is characterized by loss of focal cerebral function due to impaired of brain-blood flow. Environmental factors and genetic factors may be effective together in the pathogenesis of ischemic stroke. Trace elements are important components of the biological structure, and toxic effects may occur when these trace elements are taken in more than the amount required for biological functions. The risk of neurological diseases such as ischemic stroke may increase as a result of imbalances in trace element levels. Therefore, the aim of this study is to investigate the effects of serum iron and copper levels in the development of ischemic stroke disease.

Materials and Methods: Our study consisted of 20 ischemic stroke patients and 36 healthy controls. Serum iron and copper levels measurements were performed using atomic absorption spectrophotometer method.

Results: Serum iron and copper levels were detected significantly lower in the patient group with ischemic stroke compared to the healthy control group. However, the significant difference was not determined in comparison of serum copper and iron levels according to gender between patient with ischemic stroke and healthy control groups.

Conclusion: In our study, it was determined that serum iron and copper levels may be effective risk factors for ischemic stroke disease. Thus, it was concluded that serum iron and copper trace element levels may be important biomarkers that may be evaluated in the diagnosis, prognosis and treatment of ischemic stroke.

Keywords: Ischemic stroke; biomarkers; copper; iron; trace elements.
\end{abstract}

\section{Introduction}

Stroke is known as a focal brain defect and it occurs suddenly as a result of vascular lesions. The factors affecting the pathogenesis of stroke has been associated with the high prevalence of the disease (1). Ischemic stroke is one of stroke type and it is a neurological damage that occurs as a result of blockage within the blood vessels that supply blood to the brain $(2,3)$. Various processes such as excitotoxicity, oxidative stress,

\begin{abstract}
Özet
Amaç: İskemik inme, beyin-kan akışının bozulması nedeniyle fokal serebral fonksiyon kaybi ile karakterizedir. İskemik inme patogenezinde çevresel faktörler ve genetik faktörler birlikte etkili olabilmektedir. Eser elementler biyolojik yapının önemli bileșenleridir ve bu eser elementler biyolojik işlevler için gerekli miktardan daha fazla alındığında toksik etkiler meydana gelebilir. Eser element düzeylerindeki dengesizlikler sonucunda iskemik inme gibi nörolojik hastalık riski artabilmektedir. Bu yüzden, bu çalışmanın amacı iskemik inme hastalığının gelişiminde serum demir ve bakır düzeylerinin etkilerini araştırmaktır.

Gereç ve Yöntemler: Çalışmamız 20 iskemik inme hastası ve 36 sağl1klı kontrolden oluşmaktayd1. Serum demir ve bakır seviyeleri ölçümleri atomik absorpsiyon spektrofotometre yöntemi kullanılarak gerçekleştirildi.

Bulgular: İskemik inmeli hasta grubunda sağl1klı kontrol grubuna göre serum demir ve bakır düzeylerinin anlaml derecede düşük olduğu belirlendi. Ancak iskemik inmeli hasta ve sağlıklı kontrol grubu arasında cinsiyete göre serum demir ve bakır düzeyleri karşılaştırıldığında anlamlı farklılık saptanmadı.

Sonuç: Çalışmamızda serum demir ve bakır düzeylerinin iskemik inme hastalığı için etkili risk faktörleri olabileceği belirlendi. Böylece serum demir ve bakır eser element düzeylerinin iskemik inme tan1, prognoz ve tedavisinde değerlendirilebilecek önemli biyobelirteçler olabileceği sonucuna varild1.
\end{abstract}

Anahtar Kelimeler: İskemik inme; bakır; biyomarkerlar; demir; eser elementler.

inflammation, blood-brain barrier dysfunction, necrosis and apoptosis play an important role in the pathophysiology of ischemic stroke. Critically reduced cerebral blood flow during cerebral ischemia causes insufficient oxygen and glucose delivery, thus trigger processes of ischemic stroke pathophysiology. Ischemic stroke pathophysiology occurs in two stages. A reversible damage occurs in the tissue area called ischemic pneumbra, which is functionally impaired but structurally intact. When the cerebral blood flow decreases, brain damage becomes irreversible and brain infarction

\footnotetext{
* Sorumlu Yazar: Arzu Ay ${ }^{1}$ Department of Biophysics, Faculty of Medicine, Trakya University, Edirne, Turkey Email: arzuay78@yahoo.com Orcid: Arzu Ay 0000-0002-8412-091X, Nevra Alkanl 0000-0002-3745-8838, Sezgin Kehaya0000-0002-9608-9278
} 
may be developed (4). Therefore, ischemic stroke is a multifactorial disease and genetic and environmental factors play together a role in ischemic stroke pathogenesis (1-4). Trace elements are among environmental factors and they play an important role in preventing of neuronal damage by protecting the neurons. Also trace elements may be effective in correcting of blood flow to the ischemic area, increasing of energy and inhibiting of hippocampal neurons necrosis (3). Trace elements are important components of biological structures and they can become toxic when taken above levels required for biological functions. Trace element levels in the human body are effective in maintaining of homeostasis in biological systems (5). Some trace elements are very important in maintaining of neurons and glia metabolism. Trace elements are among environmental factors that play an important role in the pathogenesis, diagnosis and treatment of ischemic stroke. Imbalances in trace element levels has been associated with increased risk of ischemic stroke (6). Iron $(\mathrm{Fe})$ and copper $(\mathrm{Cu})$ are known as trace elements that can suffer oxidation and reduction (7). Imbalances in the levels of trace elements such as $\mathrm{Fe}$ and $\mathrm{Cu}$ can trigger the development of ischemic stroke (8). Fe is vital trace element in the body. Oxidative stress may develop as a result of Fe accumulation known as redox active metal. As a result, cellular death may occur associated with oxidative stress (8). Significant relationship has been shown between high $\mathrm{Fe}$ levels and increased risk of cerebrovascular attacks (9). Fe accumulation can lead to oxidative stress in the brains of patients diagnosed with ischemic stroke, thus cellular death may be occur $(2,10)$. Fe accumulation in ischemic tissues is associated with increased serum hepcidin levels due to inflammation and factor 1-alpha upregulation due to hypoxia (11). Cu can act as a prooxidant and it plays an important role in brain tissue thus, it is effective in ischemic stroke pathogenesis (8). $\mathrm{Cu}$ is an important trace element in the proper functioning of enzymes and it is effective in $\mathrm{Fe}$ metabolism. $\mathrm{Cu}$ is involved in reactions that can cause the production of reactive oxygen species and thus can lead to cytotoxic effects (12). The relationship has been reported between imbalances in trace element homeostasis and metalloid levels in the blood of ischemic stroke patients $(13,14)$. It has been reported that various trace elements may be effective in the pathogenesis of ischemic stroke through inflammation and oxidative stress modulation (15). It is considered that trace element levels such as $\mathrm{Fe}$ and $\mathrm{Cu}$ may be important risk factors that may play an effective role in the pathogenesis of ischemic stroke. Therefore, in this study, we aimed to investigate the effects of serum $\mathrm{Fe}$ and $\mathrm{Cu}$ levels in the development of ischemic stroke.

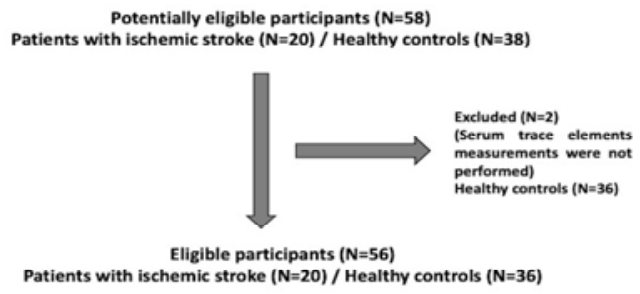

Figure 1. The flow diagram for the ischemic stroke patient and healthy control groups

\section{Materials and Methods}

For our study, ethics committee approval was obtained with the TÜTF-BAEK 2018/269 protocol code from Trakya University Faculty of Medicine Non-Invasive Clinical Research Ethics Committee. In addition, signed informed consent forms were collected from each individual in the ischemic stroke patient and healthy control groups. In our study, blood serum has been obtained from patients hospitalized at first 7 days of ischemic stroke symptom. In this study, trace element levels were measured using serum samples obtained from peripheral venous blood. The ischemic stroke patient group consisted of patients diagnosed with ischemic stroke. The healthy control group consisted of healthy volunteers who were not diagnosed with ischemic stroke. Those younger than 19 years of age, pregnant and breastfeeding women, those diagnosed with any malignancy, and those with another neurodegenerative disease were excluded from our study. This study is a study involving "People" and was conducted in accordance with the principles set out in the Helsinki Declaration 2008. Our study consisted of 20 ischemic stroke patients and 36 healthy controls. The mean age of the ischemic stroke patient group was $60.450 \pm$ 14.0131, while the mean age of the healthy control group was $58.139 \pm 11.5861$. The flow diagram for the ischemic stroke patient and healthy control groups is presented in Figure 1. Determination of serum trace element levels by atomic absorption spectrophotometer method for serum trace 


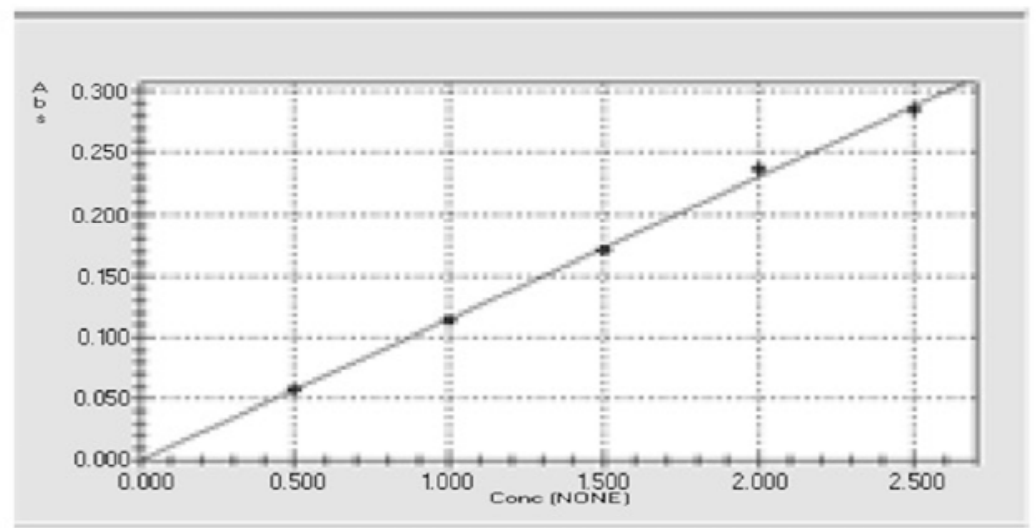

Figure 2. Concentration-calibration graph for Fe trace element

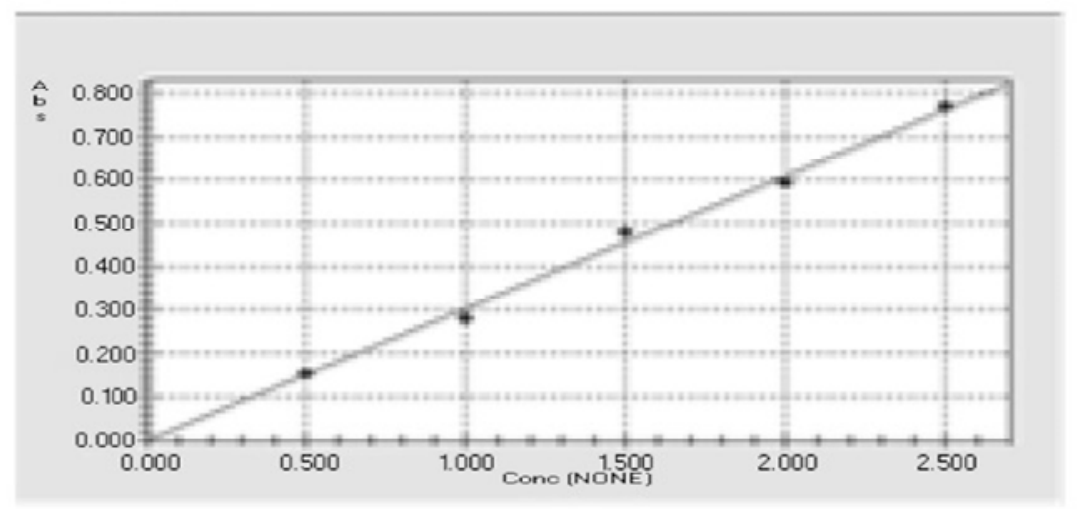

Figure 3. Concentration-calibration graph for $\mathrm{Cu}$ trace element

Table 1: Comparison of clinical parameters between patient group with ischemic stroke and healthy control group

\begin{tabular}{llll}
\hline Clinical parameters & Patient group $(\mathbf{n}=\mathbf{2 0})$ & Control group $(\mathbf{n}=\mathbf{3 6})$ & $\mathbf{p}$ \\
\hline Age $(\mathrm{year})$ & $60.450 \pm 14.0131$ & $58.139 \pm 11.5861$ & $0.510^{\mathrm{a}}$ \\
BMI $\left(\mathrm{kg} / \mathrm{m}^{2}\right)$ & $27.697 \pm 4.6588$ & $27.609 \pm 5.1803$ & $0.950^{\mathrm{a}}$ \\
Gender $($ Male $/$ Female) & $16(75.0 \%) / 4(25.0 \%)$ & $20(55.6 \%) / 16(44.4 \%)$ & $0.249^{\mathrm{b}}$ \\
Hypertension $(+/-)$ & $12(60.0 \%) / 8(40.0 \%)$ & $7(19.4 \%) / 29(80.6 \%)$ & $0.005^{\mathrm{b} *}$ \\
DM $(+/-)$ & $10(50.0 \%) / 10(50.0 \%)$ & $3(8.3 \%) / 33(91.7 \%)$ & $0.001^{\mathrm{b}^{*}}$ \\
Cholesterol $(+/-)$ & $14(70.0 \%) / 6(30.0 \%)$ & $6(16.7 \%) / 30(83.3 \%)$ & $<0.001^{\mathrm{b}^{*}}$ \\
Alcohol $(+/-)$ & $1(5.0 \%) / 19(95.0 \%)$ & $13(36.1 \%) / 23(63.9 \%)$ & $0.011^{\mathrm{b} *}$ \\
Smoking $(+/-)$ & $4(20.0 \%) / 16(80.0 \%)$ & $9(25.0 \%) / 27(75.0 \%)$ & $0.752^{\mathrm{b}}$ \\
\hline
\end{tabular}

DM: Diabetes mellitus; BMI: Body Mass Index

${ }^{a}$ Independent Samples Test

${ }^{\mathrm{b} C h i-s q u a r e}$ Test

$(+/-)$ : Existent/Absent *: Significance $(\mathrm{p}<0,05)$ 
element level measurements, blood obtained from patient group with ischemic stroke and from healthy control groups, were centrifuged at 5000 $\mathrm{rpm}$ for 5 minutes and serum was obtained from the peripheral blood. Distilled water was added to the obtained serum samples and total volume was completed to $5 \mathrm{ml}$. In addition, the total mixture was homogenized via vortexing. 0.5, 1, 1.5, 2, 2.5 $\mathrm{ppm}(\mathrm{mg} / \mathrm{l})$ standard solutions were prepared for trace elements $\mathrm{Cu}$ and $\mathrm{Fe}$. Concentrationcalibration graphs were drawn for each element by the standard solutions give to atomic absorption spectrophotometer (Figure 2, Figure 3).

Statistical analysis: Independent Samples test was used to comparison of age and body mass index (BMI) variables between patient group with ischemic stroke and healthy control group. Chisquare test were used to comparison of parameters such as gender, hypertension, diabetes mellitus, cholesterol, alcohol, smoking between patient group with ischemic stroke and healthy control group. Mann-Whitney $U$ test was used for comparison of serum $\mathrm{Cu}$ and $\mathrm{Fe}$ levels between ischemic stroke patient and healthy control groups. Mann-Whitney $U$ test was used for comparison of serum $\mathrm{Cu}$ and $\mathrm{Fe}$ levels in terms of gender between patient with ischemic stroke and control groups. The results were expressed as number (percentage) or mean \pm standard deviation. Statistical significance was accepted as $\mathrm{p}$ $<0.05$. The statistical analysis of the data obtained in our study was performed using SPSS 20.0 (Statistics Package of Social Science) statistical program.

\section{Results}

In our study, the significant difference was determined between the ischemic stroke patient and healthy control groups in terms of parameters such as hypertension, diabetes mellitus, cholesterol and alcohol $(\mathrm{p}<0.05)$. On the other hand, the significant difference was not determined between ischemic stroke patient group and healthy control group in terms of age, BMI, gender and smoking parameters $(\mathrm{p}>0.05)$ (Table 1). Serum $\mathrm{Cu}$ and $\mathrm{Fe}$ levels were determined significantly lower in the ischemic stroke patient group compared to healthy control group. The significant difference was detected in terms of serum $\mathrm{Cu}$ and $\mathrm{Fe}$ levels between the patients diagnosed with ischemic stroke and healthy control groups $(\mathrm{p}<0.05)$ (Table 2). In addition to, serum $\mathrm{Cu}$ and $\mathrm{Fe}$ levels were determined significantly lower in the male and female ischemic stroke patient group compared to male and female healthy control group. However, the significant difference was not detected in comparison of serum $\mathrm{Cu}$ and $\mathrm{Fe}$ levels in terms of gender between patient with ischemic stroke and healthy control groups ( $\mathrm{p}>0.05)$ (Table 3$)$.

\section{Discussion}

Cerebrovascular diseases are known as diseases showing glial activation and neuronal damage. Various studies have been performed to determine biochemical markers in cerebrovascular diseases such as ischemic stroke $(5,6)$. Metals are essential for normal central nervous system functions and play an important role in various biochemical processes. There are various enzymes that are effective in the synthesis, stability and protection of myelin and metals are essential cofactors for these enzymes. Basic metals that are necessary for maintaining the normal functions of biological tissues such as the brain parenchyma are classified in two groups as alkaline earth metals and basic transition metals. These metals play an important role in various physiological processes such as electron and oxygen transport, neurotransmitter synthesis, cell adhesion, protein and carbohydrate metabolism and immune response. Trace elements are transition metals and they are localised in protein active sites. They play a role as metabolic cofactors for structural and catalytic functions (16). Trace elements are among the biochemical markers that may be important in the pathogenesis of ischemic stroke and they may affect the transport and organization of substances in the blood-brain barrier (5). Iron plays an important role in the functions of the central nervous system. The role of iron in the pathogenesis of many neurodegenerative diseases has not been fully determined. However, degeneration occurs in some parts of the brain in various neurological diseases such as Alzheimer's disease, Parkinson's disease, Huntington's disease, and Friedreich's ataxia, and iron accumulation in these regions has been reported. Increased total brain iron content has been demonstrated in some neurodegenerative disorders. Adequate brain iron content is very important in normal development. As a result of imbalances such as excesses and deficiencies in iron content in the central nervous system, motor system, neurobehavioral abnormalities and neurodegenerative disorders occur (17). Copper is an important cofactor of many enzymes and 
Table 2: Comparison of trace element levels between patient with ischemic stroke and control groups

\begin{tabular}{llll}
\hline Trace elements & $\begin{array}{l}\text { Groups } \\
\text { Patient }(\mathbf{n}=\mathbf{2 0})\end{array}$ & Control $(\mathbf{n}=36)$ & p \\
\hline Serum $\mathrm{Cu}(\mu \mathrm{g} / \mathrm{dl})$ & $80.6165 \pm 29.8666$ & $139.8975 \pm 69.2275$ & $<_{\mathbf{0 . 0 0 1}}^{\mathbf{a}^{*}}$ \\
Serum $\mathrm{Fe}(\mu \mathrm{g} / \mathrm{dl})$ & $62.5425 \pm 14.4758$ & $123.6103 \pm 33.9809$ & $\mathbf{0 . 0 0 1}^{\mathbf{a}^{*}}$ \\
\hline
\end{tabular}

${ }^{a}$ Mann Whitney U test ,*: Significance $(\mathrm{p}<0,05)$

Cu: Copper; Fe: Iron

Table 3: Comparison of trace element levels according to gender between patient with ischemic stroke and control groups

\begin{tabular}{|c|c|c|c|}
\hline \multirow{2}{*}{ Trace elements } & \multicolumn{2}{|l|}{ Groups / Gender } & \multirow[t]{2}{*}{$\mathrm{p}$} \\
\hline & Patient Male & Control Male & \\
\hline \multirow{3}{*}{ Serum $\mathrm{Cu}(\mu \mathrm{g} / \mathrm{dl})$} & $15(75.0073 \pm 25.7516)$ & $20(126.7570 \pm 37.7128)$ & $0.432^{\mathrm{a}}$ \\
\hline & Patient Female & Control Female & \\
\hline & $5(97.4440 \pm 38.0013)$ & $16(156.3231 \pm 94.1425)$ & $0.504^{a}$ \\
\hline \multirow{3}{*}{ Serum Fe $(\mu \mathrm{g} / \mathrm{dl})$} & Patient Male & Control Male & \\
\hline & $\begin{array}{l}15(64.4900 \pm 16.0475) \\
\text { Patient Female }\end{array}$ & $\begin{array}{l}20(124.9110 \pm 33.9353) \\
\text { Control Female }\end{array}$ & $0.337^{\mathrm{a}}$ \\
\hline & $5(56.7000 \pm 6.0940)$ & $16(121.9844 \pm 35.0789)$ & $0.975^{\mathrm{a}}$ \\
\hline
\end{tabular}

${ }^{a}$ Mann Whitney U test ,*: Significance $(\mathrm{p}<0,05)$, Cu: Copper; Fe: Iron

proteins. It plays an important role in various biological functions such as respiration, protection from oxidative damage, iron metabolism, neurotransmitter synthesis, myelination, neuropeptide activation. Therefore, copper dysmetabolism has been associated with toxic effects in relation to oxidative stress. Imbalances in $\mathrm{Cu}$ levels have emerged in neurodegenerative disorders such as Wilson's disease, Menkes' disease, Alzheimer's disease, Parkinson's disease, Amyotrophic Lateral Sclerosis (18). Trace elements are important factors in the protection of neurons and the prevention of neuronal damage. They are also effective in improving blood flow to the ischemic area, increasing energy and preventing hypocompal neuron necrosis. Copper plays an important role in the regulation of enzyme functions and is very effective in iron metabolism. Copper can cause cytotoxic effects by producing reactive oxygen species. Increased Fe levels have also been associated with an increased risk of cerebrovascular attacks (19). Fe and $\mathrm{Cu}$ are trace elements necessary for cellular metabolism, they are transmitted to all organs, tissues and cells in the body. Excess iron is given to the bone marrow, which is necessary for the production of hemoglobin. The use of iron in the bone marrow is dependent on $\mathrm{Cu}$. During $\mathrm{Cu}$ deficiency, hemoglobin production is insufficient despite normal serum iron levels (20). Various neurodegenerative diseases such as Alzheimer's disease, Parkinson's disease, amyotrophic lateral sclerosis, multi-system atrophy, ischemic stroke, prion diseases can occur as a result of the impairment of trace element homeostasis. Excessive exposure to trace elements has been associated with various pathological processes such as induction of neurotoxicity, mitochondrial dysfunction, impairment of neurotransmitter metabolism, oxidative stress induction (16-18). Changes in trace element homeostasis have been associated with neurodegeneration etiology. Abnormal levels of trace elements such as Fe and $\mathrm{Cu}$ can adversely affect the nervous system through induction of reactive oxygen species production. Although various studies have been performed to investigate the effects of serum trace element levels on the development of neurodegenerative disorders such as ischemic stroke, the mechanism showing the relationship between trace element levels and the development of ischemic stroke has not been fully explained (21). In another study, it was found that $\mathrm{Cu}$ plays an important role in nerve tissue function (5). In a study, serum $\mathrm{Cu}$ levels were found significantly higher in patients with ischemic stroke compared 
to healthy controls (5). In another study performed with the Iranian population, serum $\mathrm{Cu}$, $\mathrm{Fe}$ and ferritin levels were detected as important risk factors for the development of the disease in patients with ischemic stroke (9). In various studies, changed $\mathrm{Cu}$ levels in nerve tissues were shown and this trace element can contribute to ischemic stroke (6). In a study performed with Russian population, serum $\mathrm{Fe}$ levels were significantly decreased and $\mathrm{Fe}$ levels may be an important risk factor for the development of ischemic stroke (8). In a study performed with the Iranian population, increased serum and urine $\mathrm{Cu}$ levels were detected as important risk factor for the development of ischemic stroke (1). In another study, increased $\mathrm{Cu}$ concentrations were determined in patients with ischemic stroke (14). In a study performed with the Indian population, decreased serum $\mathrm{Fe}$ concentrations were determined in patients with ischemic stroke compared to healthy controls. However, statistically the significant difference was not detected in terms of serum $\mathrm{Cu}$ and $\mathrm{Fe}$ levels between ischemic stroke patients and healthy control groups (13). In another study, decreased serum $\mathrm{Fe}$ concentrations were associated with an increased risk of acute myocardial infarction and ischemic stroke (22). Body homeostasis and biological processes can be affected as a result of imbalances in trace element levels. These imbalances may contribute to the development of various neurodegenerative diseases such as ischemic stroke. Fe deficiency has been associated with decreased blood hemoglobin concentration. Thus, tissue oxygen delivery is affected. A significant relationship has been reported between iron deficiency anemia and the development of ischemic stroke (23). Copper deficiency has also been associated with low hemoglobin levels and low serum iron levels. A full understanding of the interaction of $\mathrm{Cu}$ and $\mathrm{Fe}$ is very important for ischemic stroke. $\mathrm{Cu}$ and $\mathrm{Fe}$ homeostasis in brain cells is important. $\mathrm{Cu}$ and $\mathrm{Fe}$ trace elements can accumulate in various cell types in the brain and thus lead to pathological conditions that can cause oxidative stress-related damage (20). Iron deficiency anemia can lead to fatal complications and is effective in the development of cerebral infarction. Iron deficiency anemia is considered to be an important risk factor in ischemic stroke without vascular, cardiac or coagulation pathologies (24). In our study, it was determined that serum $\mathrm{Cu}$ and $\mathrm{Fe}$ levels significantly lower in patients with ischemic stroke compared to healthy controls $(p<0.05)$. The significant difference was detected between ischemic stroke patient and healthy control groups in terms of serum $\mathrm{Cu}$ and Fe levels $(\mathrm{p}<0.05)$. Also, serum $\mathrm{Cu}$ and $\mathrm{Fe}$ levels were determined significantly lower in the male and female ischemic stroke patient group compared to male and female healthy control group. However, the significant difference was not determined in terms of serum $\mathrm{Cu}$ and $\mathrm{Fe}$ levels according to gender between patient with ischemic stroke and healthy control groups ( $p>0.05)$. In our study, the fact that serum $\mathrm{Cu}$ and Fe levels were determined to be significantly lower in patients with ischemic stroke compared to healthy controls may be due to iron deficiency anemia. Therefore, anemia treatment in patients with or without ischemic stroke risk factors is extremely important in preventing the development of cerebrovascular complications such as ischemic stroke.

\section{Conclusion}

There are various studies performed with different races and populations aiming to investigate the roles of trace element levels such as serum $\mathrm{Fe}$ and $\mathrm{Cu}$ in the development of ischemic stroke and different results have been obtained in these studies. It is thought that the differences in these studies may stem from different selection criteria and sample size for patient and control groups. Important biomarkers such as serum trace element levels in the early diagnosis of ischemic stroke disease is extremely important in terms of developing new strategies in the progression and treatment of the disease. As a result, in our study with Thrace population of Turkey, significant reduction in serum $\mathrm{Cu}$ and $\mathrm{Fe}$ levels was determined as an important risk factor in development and progression of ischemic stroke disease. In conclusion, more comprehensive studies with large populations are needed to evaluate together serum $\mathrm{Cu}, \mathrm{Fe}$ trace element levels and parameters associated with anemia in ischemic stroke patients. Thus, important biomarkers that may be effective in the early diagnosis, prognosis and progression of ischemic stroke can be obtained and appropriate treatment strategies can be developed for ischemic stroke disease.

Compliance with Ethical Standards

- Ethical approval

For our study, ethics committee approval was obtained with the TUTF-BAEK 2020/269 
protocol code from Trakya University Faculty of Medicine Non-Invasive Clinical Research Ethics Committee.

- Author Contribution

All authors contributed to the study conception and design. Material preparation, data collection and analysis were performed by [Arzu Ay], [Nevra Alkanli] and [Sezgin Kehaya]. The first draft of the manuscript was written by [Arzu Ay and Nevra Alkanli]. All authors read and approved the final manuscript.

- Consent to participate

Signed informed consent form was collected from each individual in the patient group with ischemic stroke and healthy control group

- Conflict of interest

The authors declare that they have no conflict of interest.

Ethics committee approval: The approval of ethics committee was obtained from Trakya University Medical Faculty Non-Invasive Ethics Committee (Protocol code: TÜTF-BAEK 2018/269).

Informed consent: Signed informed consent forms were obtained from each of the individuals who ischemic stroke patients and healthy control groups.

Conflict of interest: We declare that there is no conflict of interest in this study.

Financial disclosure: This study was not financially supported.

\section{References}

1. Abolhasani J, Rafiee $\mathrm{P}$, Sehat M. Comparison of Copper and Zinc Concentration in Noncardioembolic Ischemic Stroke Patients with Non-Stroke Patients. J Biochem Tech 2020; 11(1): 149153.

2. Carbonell T, Rama R. Iron, oxidative stress and early neurological deterioration in ischemic stroke. Curr Med Chem 2007; 14(8): 857-874.

3. Afshari D, Moradian N, Rezaei M. Evaluation of the intravenous magnesium sulfate effect in clinical improvement of patients with acute ischemic stroke. Clin Neurol Neurosurg 2013; 115(4): 400-404.

4. Guo Y, Li P, Guo Q, Shang K, Yan D, Du $S$, et al. Pathophysiology and Biomarkers in Acute Ischemic Stroke - A Review. Trop J Pharm Res 2013; 12(6): 1097-1105.
5. Skalny AV, Klimenko LL, Turna AA, Budanova MN, Baskakov IS, Savostina MS, et al. Serum trace elements are associated with hemostasis, lipid spectrum and inflammatory markers in men suffering from acute ischemic stroke. Metab Brain Dis 2017; 32: 779-788.

6. Gönüllü H, Karadaş S, Milanlioğlu A, Gönüllü E, Katı C, Demir H. Levels of serum trace elements in ischemic stroke patients. J Exp Clin Med 2013; 30: 301-304.

7. Zangieva ZK, Torshin I, Gromova OA, Nikonov AA. Trace elements in the nervous tissue and ischemic stroke. Zh Nevrol Psikhiatr Im S S Korsakova 2013; 113: 30-36.

8. Yurtdaş G, Karabudak E, Mandıroğlu F. Hemodiyaliz hastalarının serum çinko düzeyleri ile hematolojik parametreleri arasındaki ilişki. [The relationship between serum zinc levels and hematological parameters of hemodialysis patients]. Bes Diy Derg 2018; 46(1): 16-23.

9. Karadas S, Sayın R, Aslan M, Gonullu H, Kat C, Dursun R, et al. Serum levels of trace elements and heavy metals in patients with acute hemorrhagic stroke. J Membr Biol 2014; 247(2): 175-180.

10. Selim MH, Ratan RR. The role of iron neurotoxicity in ischemic stroke. Ageing Res Rev 2004; 3(3): 345-353.

11. Petrova J, Manolov V, Vasilev V, Tzatchev $\mathrm{K}$, Marinov B. Ischemic stroke, inflammation, iron overload-connection to a hepcidin. Int J Stroke 2016; 11(1): 16-17.

12. Tapiero H, Townsend D, Tew K. Trace elements in human physiology and pathology. Copper. Biomed Pharmacother 2004; 20 (9): 386-398.

13. Munshi A, Babu S, Kaul S, Shafi G, Rajeshwar K, Alladi S, et al. Depletion of serum zinc in ischemic stroke patients. Methods Find Exp Clin Pharmacol 2010; 32(6): 433-436.

14. Kodali P, Chitta KR, Figueroa JAL, Caruso JA, Adeoye O. Detection of metals and metalloproteins in the plasma of stroke patients by mass spectrometry methods. Metallomics 2012; 4(10): 1077-1087.

15. Li YV, Zhang JH. Metal ions in stroke pathophysiology, in: Y.V. Li, J.H. Zhang 
(Eds.), Metal Ion in Stroke, Springer, New York, 2012, pp. 1-12.

16. Lin CM, Selim M. Iron neurotoxicity in ischemic and hemorrhagic stroke, in: Y.V. Li, J.H. Zhang (Eds.), Metal Ion in Stroke, Springer, New York, 2012, pp. 241-253.

17. Sipe JC, Lee P, Beutler E. Brain iron metabolism and neurodegenerative disorders. Dev Neurosci 2002; 24(2-3): 188-196.

18. Giampietro R, Spinelli F, Contino M, Colabufo NA. The Pivotal Role of Copper in Neurodegeneration: A New Strategy for the Therapy of Neurodegenerative Disorders. Mol Pharm 2018; 15(3): 808820.

19. Moemeni H, Qujeq D, Ahmadi Ahangar A, Hajian K, Parsian H. Evaluation of Serum Magnesium, Iron, Copper and Zinc Levels in Ischemic and Hemorrhagic Stroke Patients and Healthy Controls. JCBR 2018; 2(1): 6-10.

20. Collins JF, Prohaska JR, Knutson MD. Metabolic crossroads of iron and copper. Nutr Rev 2010; 68(3): 133-147.
21. Millerot-Serrurot E, Bertrand N, Mossiat C, Faure P, Prigent-Tessier A, Garnier P, et al. Temporal changes in free iron levels after brain ischemia: Relevance to the timing of iron chelation therapy in stroke. Neurochem Int 2008; 52(8): 1442-1448.

22. Marniemi J, Alanen E, Impivaara $O$, Sappanen R, Hakala P, Rajala T, et al. Dietary and serum vitamins and minerals as predictors of myocardial infarction and stroke in elderly subjects. Nutr Metab Cardiovasc Dis 2005; 15(3): 188-197.

23. Wen Y, Huang S, Zhang Y, Zhang $H$, Zhou L, Li D, et al. Associations of multiple plasma metals with the risk of ischemic stroke: A case-control study. Environ Int 2019; 125: 125-134.

24. Domaç FM, Misırlı H, Mestan E, Adıgüzel T. Demir Eksikliği Anemisi ve İskemik İnme. Haydarpaşa Numune Eğitim ve Araştırma Hastanesi Tip Dergisi 2010; $50(1)$. 